\title{
The Causality between Employees' Economic Rewards and Sustainable Performance of Nigerian Quoted Manufacturing Firms
}

\author{
Fatai Abiodun Atanda ${ }^{1}$, Taiwo Olufemi Asaolu ${ }^{1} \&$ Adewale Atanda Oyerinde ${ }^{1}$ \\ ${ }^{1}$ Obafemi Awolowo University, Nigeria \\ Correspondence: Fatai Abiodun Atanda, Department of Management and Accounting, Obafemi Awolowo \\ University, Ile Ife, Nigeria. Tel: 234-803-4242-773. E-mail: atanda2001uk@yahoo.co.uk
}

Received: September 16, 2013

Accepted: October 14, 2013

Online Published: November 18, 2013

doi:10.5539/ijbm.v8n24p25

URL: http://dx.doi.org/10.5539/ijbm.v8n24p25

\begin{abstract}
This study examines the causal relationship between employees' economic rewards and sustainable performance of the Nigerian quoted manufacturing firms. The study uses 400 firm-year data, involving 50 companies, purposively selected over the period 2006-2009. The data were sourced from the annual audited reports and accounts of the companies, obtained from the Nigerian Stock Exchange. The study uses correlation and granger causality econometric techniques to analyze the data, after carrying out diagnostic tests such as unit roots and cointegration tests. The study found that relative economic value added (WETREL) was stationary $\left(\chi^{2}=176.425\right.$, $\mathrm{p}<0.01)$ at level and relative employees' economic rewards (SENREL) stationary $\left(\chi^{2}=317.882, \mathrm{p}<0.01\right)$ at first difference, using the Philips-Perron Fisher asymptotic chi-square criterion while both WETREL was stationary $(\mathrm{Z}=-9.8012, \mathrm{p}<0.01)$ and SENREL stationary $(\mathrm{Z}=-7.2612, \mathrm{p}<0.01)$ at first difference, using Philips-Perron Choi $Z$-statistics criterion. Also, there was at least one cointegrating equation between SENREL and WETREL of the companies, indicating a long-run equilibrium relationship between the two variables. In addition, WETREL $\left(\chi^{2}=7.623, p<0.01\right)$ significantly Granger causes SENREL and SENREL $\left(\chi^{2}=3.744, p<0.05\right)$ also significantly Granger causes WETREL. Thus, a bi-directional causality existed between the variables, indicating that the direction of the causality runs two ways, from WETREL to SENREL, and vice versa. The study concluded that the two variables are good predictor of each other though employees' economic reward is a better predictor of sustainable performance of quoted manufacturing firms in Nigeria.
\end{abstract}

Keywords: sustainable performance, employees' economic rewards, EVA, manufacturing firms

\section{Introduction}

Most businesses are managed to deliver on specific performance indicators such as profit, sales and market value irrespective of whether their activities are value creating or destruction (Porter \& Kramer, 2011). They view value creation narrowly, optimizing short term financial performance and ignoring many factors that determine their long-term and sustainable performance. In fact, the performances of the manufacturing firms in Nigeria have been empirically investigated using different traditional measures (Sangosanya, 2011; Mike, 2010; Malik, Teal \& Baptist, 2004), all because the shareholders and markets want them.

However, there is the need for a change from the situation where managers are only interested in maximizing shareholders' value to where every stakeholder contributes towards sustainable performance of corporations. Sustainability implies how corporate entities can achieve short-term objectives without compromising the abilities of future generations to achieve their own objectives (Kates, Parris \& Leiserowitz, 2009). It is a concept that has began to rise and has continued to be evolving as a subject of debate among scholars, who have been trying to develop a framework for assessing the performance of corporate entities from different stakeholders' viewpoints.

One of the basic ingredients in the sustainability framework is the quantity and quality of workforce. This is because employees, an important stakeholders' group, are the people who provide the key capabilities and human resources that constitute an asset that can either grow or diminish over time, depending on how they are managed (Barber, Kotzen, Olsen \& Strack, 2002). They contribute human efforts that make it possible for corporations to create value, part of which is used to meet the challenges of compensating the employees and other stakeholders. Contemporary firms have therefore come to realize that the dynamic and fast changing world requires that they should fashion out how to address the challenges of economically rewarding their workforce. 
Or, how could a company that desires sustainable development achieve profit maximization goal at the detriment of the interests and well-being of its employees?

As widely documented in the literature, employees' reward is one of the key determinants of their performance level. However, mixed results were found because some studies found the relationship to be possitive (Campbell, 1993 and Banker, Lee, Potter and Srinivasan, 1996; Hall, Szymanski \& Zimbalist, 2002; Brown, Sturman \& Simmering, 2003; Ajila \& Awonusi, 2004; Pratheepkanth, 2011; Abosede \& Adekunle, 2012) while some others found negative relationship (Jensen \& Murphy, 1999; Murphy, 2003). Also, most of the studies concentrated on one direction i.e. how employees' economic rewards affect performance. Besides, the methodology adopted by most of the studies fell short of employing the recent developments in empirical research that emphasized causality, short-run dynamics and long-run equilibrium relationships among variables.

In addition, three important issues that have been a subject of debates require research attention. 1) Whether employees' reward is one of the fundamental reasons for sustainable performance of corporations. 2) Whether sustainable performance of corporations leads to the economic rewards given to employees. 3) Also, whether sustainable performance is a good predictor of employees' economic rewards, or/and vice versa. These issues thus imply a bi-directional relationship between employees' economic rewards and sustainable performance. However, many studies on pay-performance relationship did not empirically account for this hence, this study.

It is in this light that this study used panel data, collected from purposively selected manufacturing firms, listed in the Nigerian Stock Exchange, to test the causal relationship between employees' economic rewards and sustainable performance. Relative, rather than absolute values of employees' economic rewards and sustainable performance were however used. There are two aspects to the approach adopted in this study. Firstly, the study explored whether there is in fact, a relationship between employees' economic rewards and sustainable performance of the companies, using pooled data.

A possitive correlation between the variables will indicate that employees' economic rewards play any role in determining the performance of the companies. Also, this correlation should be strong for there to be a causal link between employees' economic rewards and sustainable performance. Secondly, the study tested whether any such causal link exists in a statistical sense, using Granger causality econometrics tool. Before this is done however, the time series properties and cointegration relationship of the data were examined.

The study used pairwise Granger causality test because the existence of correlation between the variables does not necessarily imply causation in any meaningful sense. This paper is therefore a modest contribution to the existing literature on causality between two variables and to the recent developments in human resources accounting, especially on how human resources can be used to achieve sustainable development.

\section{Literature Review}

The explanation that rewards engender performance (corporate or employees) had been continuously offered by many researchers. Early writers on the importance of employees' rewards on performance include Vroom (1964), who theoretically posited that employees tend to perform more effectively if their rewards are related to performance i.e. on objective evaluation of an employee's merit and not on personal bias or prejudice. Akerlof and Yellen (1986), also supported this assumption by positing that high pay levels can improve employees and resources efficiency by decreasing employees' unproductive behaviours.

The efficient management of employees is of importance to organizational efficiency and performance. In fact, theories have predicted relationship between employees' rewards and performance. Prominent among these are the efficiency wage theory, equity theory and stakeholder theory. The efficiency wage theory helps to explain how employees' rewards relate to organizational performance (Akerlof \& Yellen, 1986) and the results from Campbell (1993) and Banker, Lee, Potter and Srinivasan (1996) also supported this position.

More diversified results were however obtained by Williams and Dreher (1992) that high pay levels helped organizations to generate larger pools of applicants (which allowed the organizations to be more selective when hiring) and to retain highly-qualified employees (Akerlof \& Yellen, 1986; Campbell, 1993). The authors further averred that qualified employees will bring about increased productivity and hence increased corporate performance.

According to equity theory, employees often evaluate exchange relationships by comparing their perceived ratios of inputs and outputs (Adams, 1965). This is because when employees perceive inequity (for instance, when they see themselves as working harder than others but receiving rewards less than), they may respond with a host of potential negative reactions in order to restore equity in their exchange relationships (Brown, Sturman \& Simmering, 2003). The stakeholder theory also supported this by positing that a network of relationship, 
which connects a company to a greater number of interrelated individuals and constituencies, called 'stakeholders' (Donaldson \& Preston, 1995; Post, Preston \& Sachs 2002), influences the way a business is governed, its short and long-term survival.

The theory further stressed that stakeholders do not only evaluate the size of the value created that is distributed to them but also the value appropriated to other stakeholders. They also assume the presence of relative justice in the exchange process (Huppertz, Arenson \& Evans, 1978) such that the absence of relative justice in value distribution can produce negative sentiments and behavioural responses (eg., dissatisfaction and withdrawal of contributions towards value creation). However, relative justice in economic rewards to stakeholders is subjective and varies from one company to another hence, the need to examine whether corporate bodies, in modern times, control their behaviours and whether they are responding to employees' interests in an effective way.

The importance of extrinsic and intrinsic rewards was captured by the studies carried out by Ajila and Awonusi (2004) and Pratheepkanth (2011) where it was found that rewards positively and significantly related to employees' motivation. Pratheepkanth (2011) used both primary and secondary data, collected from listed firms in Sri Lanka. Ajila and Awonusi (2004), however used primary data only, collected through the use of a self-designed structured questionnaire. In the study, Pearson Product Moment correlation was used to analyze the data and the hypothesis that there is a significant relationship between extrinsic rewards and workers' performance was accepted while the hypothesis that there is significant relationship between intrinsic rewards and workers' performance was rejected. The same methodology was adopted by Abosede and Adekunle (2012), who found possitive relationship between rewards and workers' performance.

Apart from the fact that most contemporary studies are foreign-based, the studies concentrated on the impact of employees' pay on their performance and not on the performance of firms, which showed that pay-performance relationship was uni-directional. Besides, many studies on the Nigerian firms used primary data and only captured the perception of respondents. The methodology adopted by those that used secondary data also lacked rigorous empirical and econometric analysis.

While some studies used pooled longitudinal cross-sections, composed of unbalanced panel data (Brown, Sturman and Simmering, 2003; Sigler, 2011), some used cross-sectional data. Correlation, which only showed the relationship between pay and performance, was generally used and unit roots and cointegration tests were not carried out to examine the stationarity or otherwise and long-run equilibrium relationship between the variables. The causal relationship between the variables, which can help provide information about the predictive abilities of the two variables was not also investigated.

The single way direction adopted by most of the past studies on employees' pay-performance relationship calls for new researches that will test causality in order to ascertain whether the relationship is bi-directional or not. Empirical evidence on the predictive ability of sustainable performance of the Nigerian listed manufacturing companies on employees' economic rewards, and/or vice versa will therefore be made possible.

\section{Methodology}

This study used balanced panel data to test the causality between employees' economic rewards and sustainable performance of manufacturing firms listed on the Nigerian Stock Exchange. The data set contains 400 observations of 4 years from 2006 to 2009 relating to 50 selected companies and the data were obtained from their annual audited reports and accounts. The firms were purposively selected, based on data availability from nine out of 31 sectors of the Nigerian Stock Exchange classifications. Hence, only quoted manufacturing firms, on whom complete data can be collected for the periods, were included in the sample.

Sustainable performance was measured by the economic value added (EVA) by a company relative to the companies' annual average (WETREL) while employees' economic reward was measured by the salaries, wages and other emoluments of employees (including management executives) relative to annual average (SENREL). Relative figures were considered more appropriate than absolute figures because the approach helps to reduce some of the variations that characterize absolute figures, due to differences in the sizes (in terms of number of employees and capital base) of the units of analysis of this study.

Data were analyzed using correlation and econometric statistical tools. This study also employed the vector autoregressive (VAR) technique, using pairwise Granger causality. The Block Exogeneity Wald test was also used to check the robustness of the results. However, the properties of the data series were examined by testing for unit roots and co-integration. To test for unit roots, the study considered a first order autoregressive process AR (1) by applying the Phillip-Perron-Fisher and Phillip-Perron-Choi tests. This is to determine whether the 
stochastic process that generated the data series is time-invariant or not and the tests took the form

$$
\Delta y_{i t}=\alpha+\beta y_{i t-1}+\sum_{i=1}^{n} \beta \Delta y_{i t-1}+\delta_{i t}
$$

where, $y_{i t}$ is a particular variable; $\beta$ is a parameter and $\delta_{i t}$ is the error terms assumed to be white noise. This was followed by running an ordinary least square (OLS) regression of the variables at level to test for co-integration, using the Pedroni Residual Cointegration and Maximum Likelihood of Johansen (1990) tests. The existence of co-integration will show that long-run equilibrium relationship, through the vector autoregressive (VAR), exists between the variables. The existence of cointegration also suggests that there is a causal relationship between employees' economic rewards and performance, which may be uni-directional or bi-directional and hence the variables can be used to predict each other. The causal relationship was examined using the Pairwise Granger-causality test models of the form:

$$
\begin{aligned}
& \text { SENREL }_{i t}=\alpha_{0}+\sum_{i=1}^{m} \beta_{i} \text { SENREL }_{i t-1}+\sum_{j=1}^{n} \eta_{i} \text { WETREL }_{i t-j}+\mu_{i t} \\
& \text { WETREL }_{i t}=\alpha_{1}+\sum_{i=1}^{q} \lambda_{i} \text { WETREL }_{i t-1}+\sum_{j=1}^{p} \eta_{i} \text { SENREL }_{i t-j}+\pi_{i t}
\end{aligned}
$$

where, $\mu_{i t}$ and $\pi_{i t}$ are serially uncorrelated random disturbance with zero mean. From equation (2) and (3), SENREL and WETREL stand for the pair-wise series under consideration i.e. employees' economic rewards and sustainable performance, respectively. Granger causality test is related to the significance of the $\beta, \dot{\eta}, \lambda$ and $\delta$ conditional on optimal lag lengths $\mathrm{m}, \mathrm{n}, \mathrm{q}$ and $\mathrm{p}$. This means that autoregressive optimal lag order for $\beta, \dot{\eta}, \lambda$ and $\delta$ should be determined. The Theil inequality coefficient was also obtained to ascertain whether each of the variables is a good predictor of the other or not.

The study used EViews software package to test the Granger causality. Bivariate regression for all possible pairs of $(\mathrm{x}, \mathrm{y})$ series in the group was run and F-statistics for the joint hypothesis for each equation were reported. The null hypothesis is that performance of the companies does not Granger-cause employees' economic rewards for equation (2) and that employees' economic reward does not Granger-cause performance for equation (3).

\section{Results and Discussion}

\subsection{Correlation Results}

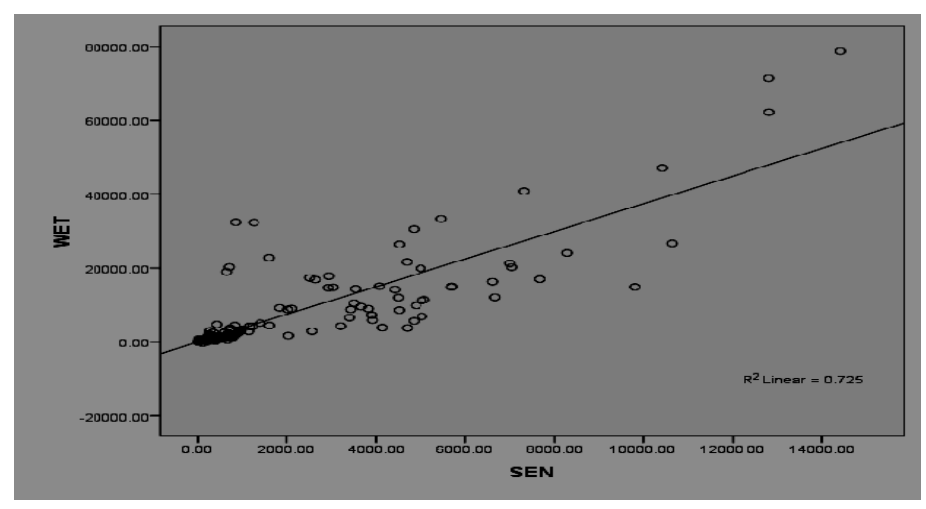

Figure 1. Relationship between WET and SEN

Before causal relationship was examined, this study, as a first step, investigated the degree of association between employees' economic rewards and firms' performance through the use of scatter graph and correlation. This is to help ascertain how the two variables have move together during the periods 2006-2009. A high correlation was detected between employees' economic rewards (SEN) and economic value added (WET) by the companies and Figure 1 is a scatter diagram that shows the relationship between the variables. The solid line is the linear regression line which indicated that $\mathrm{R}^{2}$ for this regression is about 0.73 . This means that employees' economic rewards accounted for about 73 percent of the variations in the sustainable performance of the firms.

Given that there are numerous factors that may influence the amount paid, to economically reward employees of a firm and its performance in a particular year, a more reliable measure of the variables should be used. To test 
the relationship between employees' economic rewards and performance, the estimate of employees' economic rewards relative to average annual employees' economic rewards (SENREL) and the performance of each firm relative to average annual performance (WETREL) during a year were used. Though, this process reduced the degree of variations in the variables from their means, it gives an idea of the long term relationship between relative employees' economic rewards and relative performance (see Figure 2).

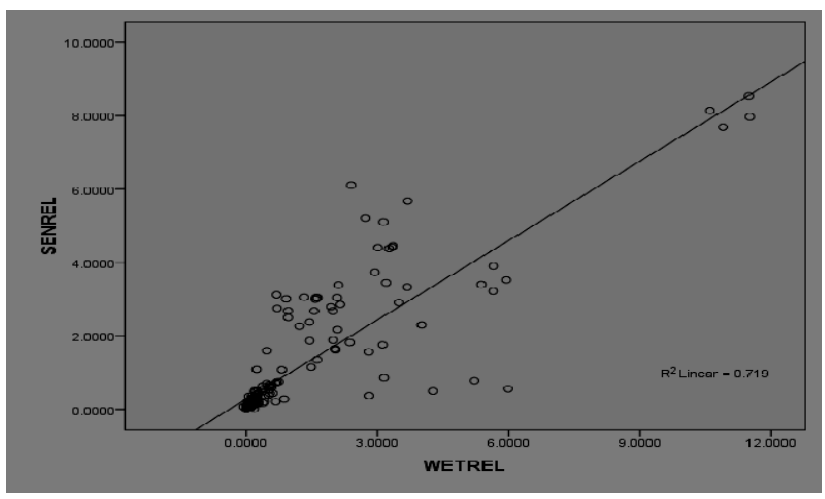

Figure 2. Relationship between WETREL and SENREL

Each dot in the graph represents a particular company and the regression line shows the relationship between the variables where $\mathrm{R}^{2}(0.719)$ gives an indication that a lesser (though, still high and possitive) degree of association exists between relative employees' economic rewards and relative performance of the companies in the longer term than as depicted in Figure 1. This result contradicted the findings of Atanda (2012) when return on capital employed was used for corporate performance because the author found negative, low and insignificant relationship between corporate performance and employees' economic rewards.

\subsection{Testing for Unit Roots Properties}

Unit roots test is carried out to examine the properties of variables that tend to change i.e. trend over time. This is to determine whether the variables should be used at level or not and to ensure that the estimates of parameters that will be obtained from regression models, using ordinary least square (OLS) are reliable, efficient and consistent. Figure 2 showed that relative employees' economic rewards and relative performance of the firms moved towards the same direction. However, the variable that determines the direction that the two of them take or the variable that caused the other to move in that direction is not known. This can only be determined by carrying out causality tests on the two variables.

Table 1. Results of panel unit roots test

\begin{tabular}{lccccc}
\hline \multirow{2}{*}{ Variables/Tests } & \multicolumn{2}{c}{ Philips-Perron Fisher } & & \multicolumn{2}{c}{ Philips-Perron Choi Z-stat } \\
\cline { 2 - 3 } \cline { 5 - 6 } & Statistics & Prob.* & & Statistics & Prob. * \\
\hline WETREL & 176.425 & 0.0000 & & -1.19671 & 0.1157 \\
SENREL & 108.743 & 0.2585 & & 1.76239 & 0.9610 \\
D(WETREL) & 317.882 & 0.0000 & & -9.80122 & 0.0000 \\
D(SENREL) & 253.628 & 0.0000 & & -7.26327 & 0.0000 \\
RESID01 & 151.173 & 0.0007 & & -1.99252 & 0.0232 \\
\hline
\end{tabular}

Source: EViews Computation by authors, 2013. Level of Significance at $5 \%$.

*Probabilities for Fisher tests are computed using an asymptotic chi-square distribution while the other assumes asymptotic normality. D signifies first differencing operator.

To examine the causal relationship, unit roots test is carried out to ensure that the panel data for the variables are stationary and that there is stationary cointegrating relationship between them, a condition for using Granger causality test. Thus, a univariate analysis of the data series was explored to examine the presence of a unit roots. According to the data in Table 1, only relative performance was stationary at level, using the Philips-Perron 
Fisher asymptotic chi-square while Philips Perron Choi Z-stat accepted the null hypothesis that relative performance was non-stationary at level i.e. the series had unit root. However, both the relative performance and relative employees' economic rewards at first difference were stationary since all the p-values were smaller than $5 \%$, using both criteria. It can therefore be concluded that the two variable series were stationary at first difference.

Table 2. VEC residual portmanteau tests for autocorrelations

\begin{tabular}{|c|c|c|c|c|c|}
\hline \multicolumn{6}{|c|}{$\begin{array}{l}\text { Null Hypothesis: no residual autocorrelations up to lag } h \\
\text { Sample: } 20062009 \\
\text { Included observations: } 50\end{array}$} \\
\hline Lags & Q-Stat & Prob. & Adj Q-Stat & Prob. & Df \\
\hline 1 & 0.000000 & NA* & 0.000000 & NA* & NA* \\
\hline 2 & 0.000000 & NA* & 0.000000 & NA* & NA* \\
\hline 3 & 0.000000 & 1.0000 & 0.000000 & 1.0000 & 6 \\
\hline 4 & 11.19649 & 0.3424 & 12.17010 & 0.2738 & 10 \\
\hline 5 & 11.19649 & 0.6705 & 12.17010 & 0.5926 & 14 \\
\hline 6 & 11.19649 & 0.8858 & 12.17010 & 0.8383 & 18 \\
\hline
\end{tabular}

Source: EViews Computation by authors, 2013. *The test is valid only for lags larger than the VAR lag order. df is degrees of freedom for (approximate) chi-square distribution.

These results were corroborated by the inverse roots of characteristic polynomial results and the estimated VAR is stable because all roots have modulus less than one and they lie inside the unit circle. This is in accordance with Lutkepohl (1991) method of testing stability of VAR. Also, the results of the autocorrelation test carried out, as indicated in Table 2, showed that the null hypothesis that there is no autocorrelations in the residuals up to lag 2 should be accepted since both the Q-statistic and Adj Q-statistic are zero.

\subsection{Autoregressive Optimal Lag Order Selection}

Optimal lag order selection is used to determine the extent to which past values of a variable can be used to predict the other variable in a system of simultaneous equations. The choice of the optimal lag length is very important in the quest for the examination of the causal relationship between variables, using the VAR/VECM models. For the selection of the joint lags, five information criteria such as sequential modified LR test statistic, Final prediction error, Akaike information criterion, Schwarz information criterion and Hannan-Quinn information criterion (each test at $5 \%$ level) were considered and the results of the tests are as shown in Table 3 .

Table 3. Results of the VAR lag order selection

\begin{tabular}{clllccc}
\hline \multicolumn{2}{l}{$\begin{array}{l}\text { Endogenous Variables: WETREL SENREL } \\
\text { Sample: } 2006 \text { 2009 }\end{array}$} & \multicolumn{2}{l}{$\begin{array}{l}\text { Exogenous Variables: C } \\
\text { Included Observations: } 50\end{array}$} \\
\hline Lag & LogL & LR & FPE & AIC & SC & HQ \\
\hline 0 & -620.4616 & NA & $2.23 \mathrm{e}+08$ & 24.89846 & 24.97494 & 24.92759 \\
1 & -489.3930 & 246.4089 & 1383675. & 19.81572 & $20.04516^{*}$ & 19.90309 \\
2 & -483.0730 & $11.37593^{*}$ & 1262378. & 19.72292 & 20.10533 & $19.86854^{*}$ \\
3 & -478.3697 & 8.089761 & $1230259 .^{*}$ & $19.69479^{*}$ & 20.23015 & 19.89866 \\
\hline
\end{tabular}

* Signifies the optimal lag length suggested by each of the criteria in each case. LR: sequential modified LR test statistic, FPE: Final prediction error, AIC: Akaike information criterion, AIC: Akaike information criterion, SC: Schwarz information criterion, HQ: Hannan-Quinn information criterion.

Source: EViews computations by authors, 2013.

The criteria suggested 1,2 and 3 optimal lag lengths. Due to the conflict in the choice of the optimal lag length by the criteria, stability test was performed to determine the most efficient lag length order and the Autoregressive (AR) roots characteristics polynomial (results not reported in this paper) and the VEC residual Portmanteau test for autocorrelations in Table 2 indicated a maximum lag of 2 . Therefore, we used a lag order of 2, based on sequential modified LR test statistic and Hannan-Quinn information criteria. 


\subsection{Test for Cointegration Results}

After establishing that the data series for the variables are non-stationary, using the criteria stipulated in the last section, the Pedroni (1999) panel cointegration test was used to investigate the existence of cointegration equilibrium long run relationship between relative employees' economic rewards and relative performance. The technique was used because it allows for multiple regressors for the cointegrating vector to vary across different sections of the panel and also for heterogeneity in the errors across cross-sectional units.

Table 4. Results of pedroni panel cointegration test

\begin{tabular}{lcc}
\hline Statistics & Value & Probability \\
\hline Panel v-Statistic & 1.878268 & 0.0302 \\
Panel rho-Statistic & -1.327952 & 0.0921 \\
Panel PP-Statistic & -2.234564 & 0.0127 \\
Panel ADF-Statistic & NA & NA \\
Group rho-Statistic & 3.411827 & 0.9997 \\
Group PP-Statistic & -9.503783 & 0.0000 \\
Group ADF-Statistic & NA & NA \\
\hline
\end{tabular}

Source: EViews Computation by authors, 2013. Level of Significance is 5 percent.

The panel autoregressive coefficients (i.e. within dimension) panel Pedroni tests, which were based on pooling the autoregressive coefficients or calculating the average statistics for the cointegration across different sections of the panel are the first four statistics shown in Table 4(a). The within dimension implied that the first order AR coefficient is restricted to be the same for all the companies. The rejection of the null hypothesis therefore means that the panel series are cointegrated for all the panel members.

However, the individual AR coefficients (i.e. between dimensions) panel Pedroni tests that are based on averaging the AR coefficient for each member of the panel, are the last three statistics in the table. This means that the AR is allowed to vary among the companies and hence, the rejection of null hypothesis indicated that there is cointegration relationship for one cross-section member of the panel and that the panel statistics provide for heterogeneity among the members of the panel.

Table 5. Test for the number of cointegrating vectors using johansen procedure

\begin{tabular}{|c|c|c|c|c|c|c|c|}
\hline \multirow{3}{*}{\multicolumn{3}{|c|}{$\begin{array}{l}\text { Series: SENREL WETREL } \\
\text { Included observations: } 50 \text { after adjustments } \\
\text { Lags interval (in first differences): } 1 \text { to } 2\end{array}$}} & \multicolumn{5}{|c|}{ Sample (adjusted): 20062009} \\
\hline & & & \multicolumn{5}{|c|}{ Test Assumption: Linear deterministic trend in the data } \\
\hline & & & & & & & \\
\hline \multicolumn{3}{|c|}{$\begin{array}{c}\text { Trace Statistics } \\
\end{array}$} & \multicolumn{4}{|c|}{ Maximum-Eigen Statistics } & \multirow[b]{2}{*}{$\begin{array}{l}\text { Hypothesized No. } \\
\text { of CE(s) }\end{array}$} \\
\hline Eigen Values & Trace Value & $\begin{array}{l}\text { Critical } \\
\text { values }(5 \%)\end{array}$ & Prob. $* *$ & $\begin{array}{l}\text { Max. Eigen } \\
\text { Value }\end{array}$ & $\begin{array}{l}\text { Critical } \\
\text { values }(5 \%)\end{array}$ & Prob. ** & \\
\hline 0.516153 & 36.44528 & 15.49471 & 0.0000 & 36.29936 & 14.26460 & 0.0000 & None* \\
\hline 0.002914 & 0.145916 & 3.841466 & 0.7025 & 0.145916 & 3.841466 & 0.7025 & At most 1 \\
\hline \multicolumn{2}{|l|}{ SENREL } & WETREL & \multicolumn{2}{|c|}{$\mathrm{C}$} & & & \\
\hline \multicolumn{2}{|l|}{1.000000} & -1.713457 & \multirow{3}{*}{\multicolumn{2}{|c|}{$35.84250(0.19260)$}} & & & \\
\hline \multicolumn{2}{|l|}{ Log likelihood } & -478.4426 & & & & & \\
\hline \multicolumn{3}{|c|}{ SENREL -1.713457 WETREL +35.84250} & & & & & \\
\hline
\end{tabular}

\footnotetext{
* denotes rejection of the hypothesis at the 0.05 level. Likelihood Ratio test, using trace and Max-Eigen statistics, indicates 1 cointegrating eqn(s) at the 5\% significant level. **MacKinnon-Haug-Michelis (1999) p-values. Normalized cointegrating coefficients (standard error in parentheses): 1 Cointegrating Equation(s).
}

Source: EViews Computation by authors, 2013.

The data in table 4 indicated that Panel v-statistic, which is the variance test ratio and Panel PP-statistic were significant at 5\% while Panel rho-statistic was significant at 10\% because they had statistics greater than critical 
value of -1.645 . This means that the null hypothesis of no cointegration should be rejected. Also, the group PP-statistic of -6.584 is also greater than -1.645 and also supported the position that the null hypothesis should be rejected. To test for the robustness of these results, Eigen values and Trace statistics were also obtained.

The unrestricted cointegration rank tests using Trace and Maximum-Engel statistics indicated that there is only one cointegrating equation at $5 \%$ level of significance since the null hypothesis of no cointegration was rejected because the calculated Trace statistic of 36.44528 and Maximum-Engel statistic of 36.29936 are greater than the critical values of 15.49471 and 14.26460 , respectively. The possitive coefficient, in each case, indicated that relative employees' economic rewards and relative performance have moved in the same direction in the long run and that the two variables are good predictors to each other. Thus, causal relationship between the two exists.

\subsection{Pairwise Granger Causality Test Results}

Granger causality test provides avenue for researcher to examine the direction of the relationship between two or more variables in a system that are endogenous i.e. whether the relationship is uni-directional or bi-directional. The direction(s) of the causality between relative employees' economic rewards (SENREL) and relative performance (WETREL) and the significance of the relationship were obtained from the use of pairwise Granger causality test for lag length of 2 .

Table 6. Results of pairwise granger causality test

\begin{tabular}{lllr}
\hline Sample: 20062009 & & & \\
Lags: 2 & Obs. & F-Statistic & Probability \\
Null Hypothesis & 100 & 7.62313 & 0.0009 \\
\hline D(WETREL) does not Granger Cause D(SENREL) & 100 & 3.74420 & 0.0272 \\
\hline D(SENREL) does not Granger Cause D(WETREL)
\end{tabular}

Source: EViews Computation by authors, 2013.

Estimates from the causality test are as presented in Table 6 . The data in the table showed that we cannot accept the two hypotheses that SENREL does not Granger cause WETREL and that WETREL does not Granger cause SENREL. It therefore appears that Granger causality runs two ways, both from SENREL and WETREL. These results confirmed the results of previous studies on the relationship between pay and performance (Ajila and Awonusi, 2004; Pratheepkanth, 2011; Abosede \& Adekunle, 2012).

Table 7 . VAR granger causality/block exogeneity wald tests

\begin{tabular}{cccc}
\hline $\begin{array}{l}\text { Sample: } 20062009 \\
\text { Included observations: } 100\end{array}$ & & \\
\hline Dependent variable: D(SENREL) & & & \\
\hline Excluded & Chi-sq. & Df & Probability \\
D(WETREL) & 15.24626 & 2 & 0.0005 \\
All & 15.24626 & 2 & 0.0005 \\
\hline Dependent variable: D(WETREL) & & & Pf \\
Excluded & Chi-sq. & 2 & 0.0237 \\
D(SENREL) & 7.488404 & 2 & 0.0237 \\
All & 7.488404 & & \\
\hline
\end{tabular}

Source: EViews Computation by authors, 2013.

The Block Exogeneity Wald test was also carried out to serve as robustness checks and the results in Table 7 confirmed the bi-directional relationship between the variables. With chi-square of $15.246(p<0.05)$ and chi-square of $7.488(p<0.05)$, the null hypothesis that the relative performance does not Granger cause relative employees' economic rewards and the hypothesis that relative employees' economic rewards do not Granger cause relative performance should be rejected, respectively. 

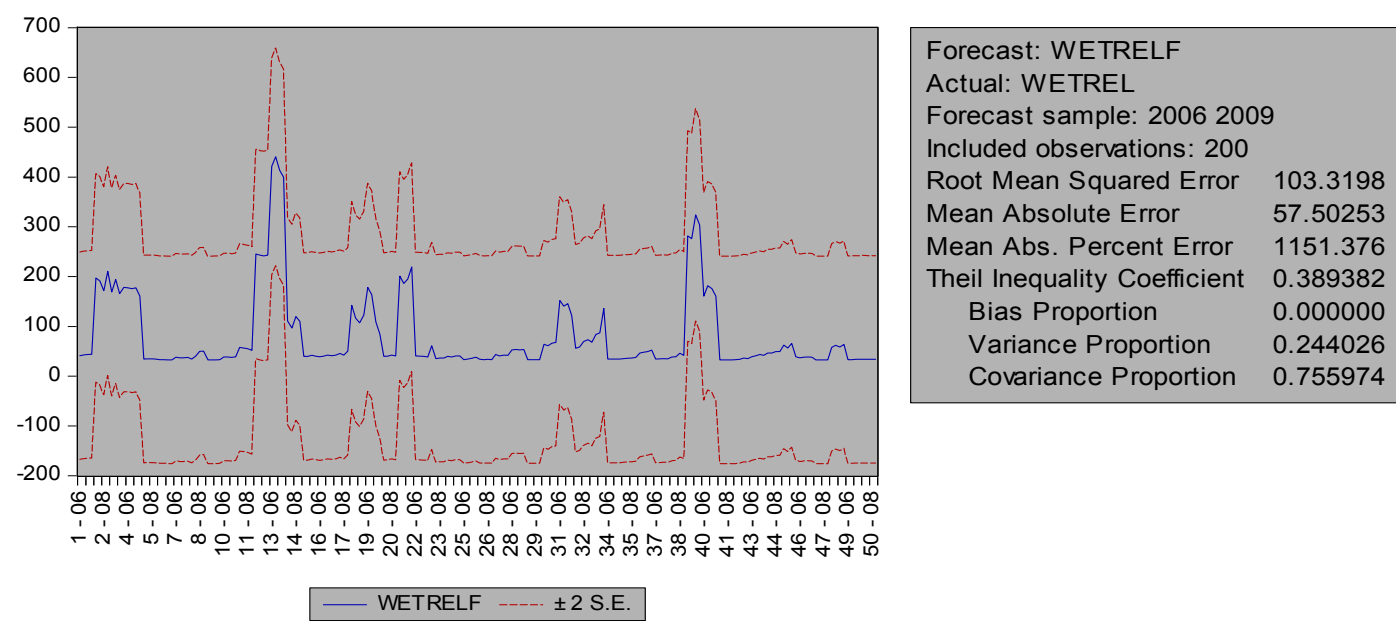

Figure 3. SENREL as a predictor of WETREL

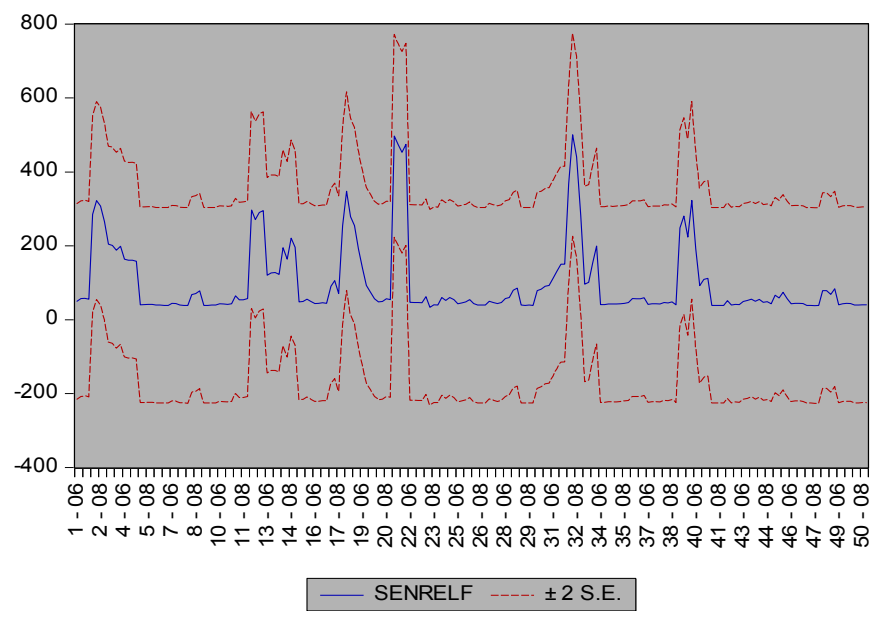

\begin{tabular}{|ll|}
\hline Forecast: SENRELF \\
Actual: SENREL \\
Forecast sample: 20062009 \\
Included observations: 200 \\
Root Mean Squared Error & 131.2319 \\
Mean Absolute Error & 71.20699 \\
Mean Abs. Percent Error & 618.4214 \\
Theil Inequality Coefficient & 0.391486 \\
$\quad$ Bias Proportion & 0.000000 \\
Variance Proportion & 0.244026 \\
Covariance Proportion & 0.755974 \\
\hline
\end{tabular}

Figure 4. WETREL as a predictor of SENREL

Since the Granger causality test confirmed that causality runs either way, this study proceeded to test whether relative employees' economic reward is a good predictor of relative performance of the firms; and vice versa, using the Theil Inequality test. Figure 3 and 4 were used to report the predictive abilities of the two variables. The Theil inequality coefficient of 0.3894 in Figure 2 indicated that relative employees' economic reward is a good fit for determining relative performance of the firms. This shows that the more the economic rewards given to employees, the more the performance, in terms of value creation, that will be recorded by the firms.

A coefficient of 0.3915 in Figure 4 also implied that relative performance is a good fit for determining relative employees' economic rewards. These results confirmed the results earlier obtained when unrestricted cointegration test was carried out. However, relative employees' economic reward is a better predictor of relative performance than relative performance a good predictor of relative employees' economic rewards because 0.392 , for relative corporate performance is nearer to 1.000 than 0.389 , for relative employees' economic rewards.

\section{Summary and Conclusion}

This study used balanced panel data to empirically investigate the causal relationship between employees' economic rewards and sustainable performance of manufacturing firms listed in the Nigerian Stock Exchange. Due to the nature of the data, the study employed econometrics analysis techniques and conduct some tests to establish the stationarity and cointegrating characteristics of the data using the Phillips-Perron-Fisher and Phillips-Perron-Choi Z-statistics for unit roots (i.e. stationarity) and Pedroni panel cointegration tests for the number of cointegrating equation vectors. Also, stability test was conducted on the VAR models estimates by 
using the results of the residual test on the roots of AR Characteristic polynomial, to ensure that inferences or forecasts from this study will be valid. All these were in addition to the descriptive and inferential statistics obtained from data analysis.

The correlation between relative employees' economic rewards and relative performance of the firms was found to be high and possitive indicating that there was a high degree of association between the two variables and that the two variables moved towards the same direction during the periods. The econometric results, based on the data collected from the companies, can be summarized as follow:

a) The unit roots test showed that the data is stationary at first difference and that they are integrated of order one i.e. AR (1), which implies that there is at least one cointegrating equation between relative employees' economic rewards and relative performance of quoted manufacturing companies in Nigeria.

b) The results of the cointegration tests also supported the evidence of at least a causal and long-run relationship between relative employees' economic rewards and relative performance.

c) The results of the pairwise Granger causality test gave evidence of bi-directional causal links between relative employees' economic rewards and relative performance, which was not empirically documented by most of the previous studies on pay-performance. This means that an increase in employees' economic rewards today signals the expectation of an increase in the performance of the firms, and vice versa.

d) Both the relative employees' economic rewards and relative performance of the firms is a good predictor of each other.

Based on these findings, it can be concluded that the economic rewards given to employees significantly contributed to the sustainable performance level achieved by the Nigerian quoted manufacturing firms, and vice versa but employees' economic reward is a better predictor of sustainable performance of the companies.

The findings and the conclusions have economic implications on value creation and sustainability in that sustainable performance of the firms Granger caused employees' economic rewards, which provided supports for efficiency wage theory and the works of Sigler (2011) and Brown, Sturman and Simmering (2003). The theory was supported in that employees' economic rewards led to efficient resources use by the employees and hence sustainable performance. Also, that sustainable performance was not as good as employees' economic rewards in predicting each other implied that there is need to distribute more value to employees than obtainable currently in the firms.

Besides, the results showed that past values of employees' economic rewards and sustainable performance can be used to predict the amount of economic value that can be created by the firms and the amount of economic rewards that can be given to employees. It is therefore important that the firms should have policies that can help them improve more on the proportion of the value created, which is distributed to employees so that more sustainable value can be created in the future. On the other hand, since the relationships between pay and performance in this study were found to be mutual and bi-directional, the employees, too, should continue to engage in activities that will further promote productivity and efficiency in resources use so that more value can be created and distributed to them.

\section{References}

Abosede, A., \& Adekunle, O. (2012). Rewards System as a Predicator of Workers Job Performance: The Case of Health Workers in Lagos State, Nigeria. International Journal of Business and Behavioural Sciences, 2(11), 7-17.

Adams, J. (1965). Towards an Understanding of Inequity. Journal of Abnormal and Social Psychology, 67, 422-436. http://dx.doi.org/10.1037/h0040968

Ajila, C., \& Awonusi, A. (2004). Influence of Rewards on Workers' Performance in an Organization. J. Soc. Sci., $8(1), 7-12$.

Akaike, H. (1969). Fitting Autoregressive Models for Regression. Annals of the Institute of Statistical Mathematics, 21, 243-247. http://dx.doi.org/10.1007/BF02532251

Akerlof, G., \& Yellen, J. (1986). Efficiency Wage Models of the Labour Market. Cambridge, England: Cambridge University Press.

Asogwa, R. (2009). Measuring the Determinants of Value Creation for Publicly Listed Banks in Nigeria: A Random Effects Probit (REP) Model Analysis. Paper Presented at the $14^{\text {th }}$ Annual Conference on Econometric Modeling for Africa, 8-10th July. 
Atanda, F. (2012). Corporate Performance and Stakeholders' Economic Rewards in Nigerian Quoted Manufacturing Companies. Proceedings of the First Annual International Conference on Accounting, Finance and Management, Obafemi Awolowo University, Nigeria, June 10-13th. pp. 2-20.

Banker, R., Lee, D., \& Srinivason, D. (1996). Contextual Analysis of Performance Impact of Outcomebased Incentive Compensation. Academy of Management Journal, 39, 920-948. http://dx.doi.org/10.2307/256717

Barber, F., Kotzen J., Olsen, E., \& Strack, R. (2002). Quantifying Employee Contribution. In Mahoney, W. (Eds.), Shareholder Value (Vol. 2, No. 3).

Brown, M., Sturman, M., \& Simmering, M. (2003). Compensating Policy and Organizational Performance: TheEfficiency, Operational and Financial Implications of Pay Levels and Pay Structure. The Academy of Management Journal, 46(6), 752-762. http://dx.doi.org/10.2307/30040666

Campbell, C. (1993). Do Firms Pay Efficiency Wages? Evidence with Data at the Firm Level. Journal of Labour Economics, 11, 4242-470.

Core, J., Holthausen, R., \& Larcker, D. (1999). Corporate Governance, Chief Executive Officer Compensation and Firm Performance. Journal of Financial Economics, 51(3), 371-406. http://dx.doi.org/10.1016/S0304-405X(98)00058-0

Donaldson, T., \& Preston, L. (1995). The Stakeholder Theory of the Corporation: Concepts, Evidence and Implications. The Academy of Management Review, 20(1), 65-91.

Granger, C. (1969). Investigating Causal Relationships by Econometric Models and Cross Spectral Methods. Econometrica, 37, 424-438. http://dx.doi.org/10.2307/1912791

Hall, S., Szymanski, S., \& Zimbalist, A. (2002). Testing Causality between Team Performance and Payroll: The Case of Major League Baseball and English Soccer. Journal of Sports Economics, 3(2), 149-168.

Huppertz, J., Arenson, S., \& Evans, R. (1978). An application of Equity Theory to Consumer-Merchant Exchange Situations. Journal of Marketing Research, 15(2), 250-260. http://dx.doi.org/10.2307/3151255

Huselid, M. (1995). The Impact of Human Resource Management Practices on Turnover, Productivity, and Corporate Financial Performance. Academy of Management Journal, 38, 635-72.

Jensen C., \& Murphy, K. (1999). Performance Pay and Top Management Incentives. Journal of Political Economy, 98(2), 225-264. http://dx.doi.org/10.1086/261677

Johansen, S. (1991). Estimation and Hypothesis Testing of Cointegration Vectors in Gausian Vector Autoregressive Models. Econometrica, 59, 1551-1580. http://dx.doi.org/10.2307/2938278

Kanagaretnam, K., Lobo, G., \& Mohammad, E. (2008). Determinants and Consequences of Large CEO Pay. Int. J. Accounting and Finance, 1(1), 61-82. http://dx.doi.org/10.1504/IJAF.2008.020237

Kates, R., Parris, T., \& Leiserowitz, A. (2009). What is Sustainable Development? Goals, Indicators, Values and Practice. Environment Science and Policy for Sustainable Environment. Retrieved from http://www.environmentmagazine.org/Editorials/Kates-apro5-full.html

Levine, D. (1993). What Do Wages Buy? Administrative Science Quarterly, 38(3), 462-483.

Lutkepohl, H. (1991). Introduction to Multiple Time Series Analysis. Berlin: Springer-Verlag. http://dx.doi.org/10.1007/978-3-662-02691-5

Malik, A., Teal, F., \& Baptist, S. (2006). The Performance of Nigerian Manufacturing Firms: Report on the Nigerian Manufacturing Enterprise Survey. A Report submitted to the Centre for the Study of African Economies. UK: University of Oxford, April.

Mike, J. (2010). The Structure of the Nigerian Manufacturing Industry. The National Workshop on Strengthening Innovation and Capacity Building in the Nigerian Manufacturing Sector. Retrieved from http://www.uneca.org/istd/documents/NigeriaManufacturing

Murphy, K. (2003). Stock-based Pay in New Economy Firms. Journal of Accounting and Economics, 34(1), 129-147. http://dx.doi.org/10.1016/S0165-4101(02)00090-3

Pedroni, P. (1999). Critical Values for Cointegration Tests in Heterogeneous Panels with Multiple Regressors. Oxford Bulletin of Economics and Statistics, 61, 653-670. http://dx.doi.org/10.1111/1468-0084.61.s1.14

Phillip, P., \& Perron, P. (1988). Testing for a Unit root in Time Series Regression. Biometrika, 75(2), 335-346. http://dx.doi.org/10.1093/biomet/75.2.335 
Porter, M., \& Kramer, M. (2011). Creating Shared Value. How to Reinvent Capitalism and Unleash a Wave of Innovation and Growth. Harvard Business Review.

Post, J., Preston, L., \& Sachs, S. (2002). Managing the Extended Enterprise: the New Stakeholder View. California Management Review, 45(1), 6-28. http://dx.doi.org/10.2307/41166151

Pratheepkanth, P. (2011). Reward System and its Impact on Employees' Motivation in Commercial Bank of Sri Lanka Plc in Jaffana District. Global Journal of Management and Business Research, 11(4), 84-92.

Sangosanya, A. (2011). Firms Growth Dynamics in Nigeria's Manufacturing Industry: A Panel Analysis. Journal of Applied Econometric Review, 1(1), 1-18.

Sigler, K. (2011). Chief Executive Officers' Compensation and Company Performance. Business and Economics Journal, 1-8.

Vroom, V. (1964). Work Motivation. New York: John Willey and Sons.

Williams, M., \& Dreher, G. (1992). Compensation System Attributes and Applicant Pool Characteristics. Academy of Management Journal, 35, 571-595. http://dx.doi.org/10.2307/256487

\section{Copyrights}

Copyright for this article is retained by the author(s), with first publication rights granted to the journal.

This is an open-access article distributed under the terms and conditions of the Creative Commons Attribution license (http://creativecommons.org/licenses/by/3.0/). 